\title{
Analisis Kesiapan Manajemen Terhadap Implementasi Perubahan Organisasi Pengelolaan SDM Single Grade di PT Pertamina (Persero) Marketing Operation Region V
}

\author{
Roy Stefanus Fanggidae \\ PT.Pertamina (Persero) Finance MOR V Surabaya (roy_san@pertamina.com) \\ Dwi Ratmawati \\ Departemen Manajemen Universitas Airlangga \\ Tri Siwi Agustina \\ Departemen Manajemen Universitas Airlangga (agustina2772@gmail.com)
}

\begin{abstract}
Current bussiness world move dynamically and require organization's effectiveness in implementation of policy changes as a form of company's efforts towards becoming a World Class Company. Organizations mostly have always introduced large or minor changes which are adaptive. Therefore, any changes in organization must be planned and managed at best. The process of changes must be managed skillfully in order to effectively implemented align with the interests of the organization. PT Pertamina (Persero) had implemented Single Grade policy as the organization effort in the implementation of changes.

These studies describe the process of change that have occured in PT Pertamina (Persero) Marketing Operation Region $\vee$ with 17 (seventeen) key element of diagnosing changes by using the model of Readiness for change by Stewart namely sponsorship, leadership, motivation, direction, measurements, organizational context, processes or functions, competitor benchmarking, customer focus, rewards, organizational structure, communication, organizational hierarchy, prior experience with change, morale, innovation, and decision making. These studies used qualitative research method with explanatory type research (explanatory). These studies use a holistic case study, using interviews, observation and see the company's internal documents to obtain the necessary data.

The results show that there is a real effort of PT Pertamina (Persero) Marketing Operation Region $\mathrm{V}$ in making changes. The process of changes shown in seventeen key elements of diagnosing changes resulted in increased employee performance. The company's effort in implementing changes encouraged employees to improve their competence and self ability, and also to be fully responsible for the tasks given. The process of changes is still underway and requires continuous monitoring and evaluation, in order to understand the development of changes so it always evolving towards the better. Subsequent studies can be done with more evidence sources and different methods.
\end{abstract}

Key words: organizational change, model Readiness for change, 17 (seventeen) key elements, single grade.

\section{PENDAHULUAN}

Saat ini dunia bisnis bergerak secara dinamis dan menuntut keefektifan organisasi dalam penerapan implementasi perubahan kebijakan sebagai bentuk upaya perusahaan untuk menuju menjadi Perusahaan Kelas Dunia. Hampir semua organisasi selalu memperkenalkan perubahan-perubahan kecil dan besar yang adaptif. Oleh karena itu, setiap perubahan dalam organisasi harus direncanakan dan di kelola sebaik mungkin. Proses perubahan harus dikelola secara terampil agar perubahan tersebut terjadi secara efektif demi kepentingan organisasi.

PT Pertamina (Persero) dalam implementasi perubahan organisasi menerapkan Single Grade adalah sebuah keharusan. Single Grade merupakan salah satu bentuk perubahan terhadap sistem pembinaan serta remunerasi sebagai bentuk upaya Perusahaan untuk menuju menjadi perusahaan kelas Dunia. Pengelolaan SDM single grade merupakan salah satu strategi perusahaan untuk mengubah mindset dan cara kerja pekerja secara 


\section{Roy Stefanus Fanggidae \\ Dwi ratmawati \\ Tri Siwi Agustina}

fundamental mengenai apa yang yang dituntut dalam pekerjaan. Hal utama yang dilakukan adalah mengubah sistem pembinaan dual grade menjadi single grade perubahan sistem ini dimaksudkan agar tidak terjadi ketimpangan pada pencapaian kinerja dan kontribusi tim sehingga internal equity dan external competitiveness dapat terjaga. Implementasi restrukturisasi pengelolaan SDM dual grade menjadi single grade dilakukan untuk mendukung tercapainya Aspirasi Pertamina Energizing Asia 2025. Semua pekerja akan mempunyai technical competencies dan tercapai high performance organization dan fairness sehingga pekerja akan semakin terpacu meningkatkan kinerja dan kompetensinya untuk posisi yang lebih baik dan tidak semata-mata untuk mendapatkan kompensasi yang lebih tinggi. Semangat yang dibawa oleh perusahaan terkait penerapan Single Grade adalah 1) Akselerasi High Performing Organization, 2) Mendorong pengembangan kapabilitas pekerja (Aktualisasi Diri), 3) Meningkatkan Internal Equity. Yang pada akhirnya membawa Perusahaan menuju World Class Energy Company.

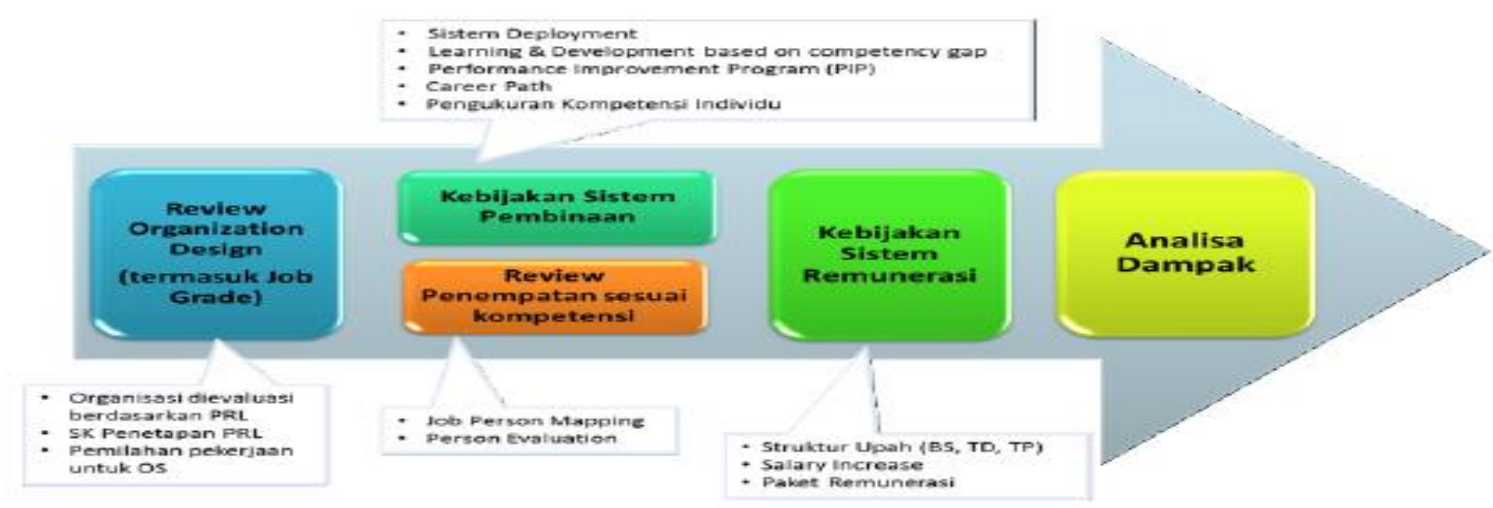

Sumber: Buletin Energia Pertamina No.1 1/thn XLVIII/November 2013

\section{Gambar I.1 \\ Tahapan Restrukturisasi Pengelolaan SDM}

Proses Review Organisasi Design dimaksudkan untuk menentukan job grade/PRL (Pertamina Reference Level) didasari konsep perubahan organisasi dari bentuk piramida menjadi bentuk diamond. Pertamina Reference Level (PRL) adalah struktur kelompok nilai jabatan yang berlaku di perusahaan yang merujuk pada konsep dan praktik umum internasional, Hay Reference Level (HRL). Review Penempatan Sesuai kompetensi dimaksudkan untuk menentukan kesesuaian antara profil dan bobot jabatan dengan profil individu, melalui Job Person Mapping (JPM). Ada dua tahapan dalam melakukan Job Person Mapping (JPM) yaitu Person Evaluation dan Placement. Person Evaluation merupakan proses identifikasi dan penilaian terhadap tingkat keahlian (person size), shape (skill group), dan profil pekerja yang bersangkutan. Tujuan adalah tersedianya data dan informasi mengenai kedalaman dan jenis keahlian, yang dapat digunakan sebagai salah satu referensi penempatan pada masa persiapan implementasi. Tahapan Placement merupakan proses melihat kesesuaian antara size-shape-profile yang dimiliki pekerja, dan sebagai salah satu dasar untuk penempatan pekerja. Review seluruh sistem dalam pola pembinaan yaitu sistem deployment, learning \& development based on competency gap, performance management system, career path dan succession planning. Setiap pekerja harus mempunyai Individual Development Plan (IDP) untuk melihat kebutuhan pengembangan dan kariernya. Dengan adanya Individual Development Plan (IDP), akan mudah bagi atasan dan Human Resources (HR) untuk menyusun program-program ke depannya. Kebijakan Sistem Remunerasi diarahkan untuk memberikan penghargaan yang berbasis pada kesesuaian antara kompetensi individu dan nilai jabatan. Implementasi dan Evaluasi seluruh proses pengelolaan SDM berbasis Jabatan.

Dalam mendukung pembinaan Sumber Daya Manusia (SDM) berdasarkan skill group dan career path yang jelas, maka setiap jabatan didefinisikan dalam Pertamina career 
structure tertentu, pertamina career structure disusun berdasarkan nilai PRL sehingga pengembangan organisasi dapat lebih efisien dan efektif.

Dengan adanya perubahan dalam implementasi single Grade di PT Pertamina akan berdampak pada: 1) Penentuan Pertamina Reference Level (PRL) masing-masing jabatan serta fasilitas-fasilitasnya dari Golongan Pekerja Biasa, Madya, Pembina, Utama. 2) Perubahan hak dan benefit yang akan diterima pekerja dengan diberlakukannya Single Grade. 3) Sistem remunerasi. Upah atau Take Home Pay terdiri dari Upah Tetap (UT), Tunjangan Posisi (TP), Tunjangan Daerah (TD) serta tunjangan-tunjangan lainnya.

Berdasarkan observasi awal pada tanggal 12 Pebruari 2014 di TBBM Surabaya Group didapati informasi dari pekerja bahwa Single Grade di implementasikan dan ada kenaikan Pertamina Reference Level maka Take Home Pay pekerja akan meningkat dikarenakan jumlah tunjangan-tunjangan lainnya meningkat, sedangkan Upah Tetap berpotensi Tetap/stop/tidak berubah apabila kita masih di dalam satu kelompok jabatan. Secara jangka pendek mungkin akan terasa menguntungkan namun efek jangka panjangnya nanti saat pensiun, saat kita diberikan upah pensiun serta pesangon maka jumlahnya akan sangat jauh berbeda (lebih rendah) dari sistem saat ini, dikarenakan segala bentuk perhitungan upah pensiun, pesangon, THR, due date cuti, Bonus, Insentif, mengacu pada Upah Tetap.

Berikut ilustrasi kelompok jabatan:

1. Kelompok Jabatan "Junior Operator" (PRL 8 dan 9)

2. Kelompok Jabatan "Senior Operator" (PRL 10 dan 11)

3. Kelompok Jabatan "Supervisor" (PRL 12 dan 13)

Selama kita di PRL 8 kemudian naik ke PRL 9 (masih di dalam kelompok jabatan yang sama "Junior Operator" maka Upah Tetap kita tetap, yang meningkat hanya Tunjangan daerah, tunjangan posisi, dan tunjangan lainnya). Kecuali kita naik PRL dari PRL 9 ke PRL 10 (lompat kelompok jabatan) maka Upah Tetap, Tunjangan Daerah, dan Tunjangan Posisi akan meningkat keseluruhan. Pada prinsipnya Upah Tetap akan tetap bertambah setiap tahun dikarenakan ada General Increase sebagai kompensasi adanya inflasi dan ada merit increase sebagai kompensasi kinerja (penilaian). Namun Promotion Increase menjadi komponen kenaikan Upah Tetap yang terbesar dan ini yang berpotensi untuk terhenti.

Penelitian ini dibatasi pada ruang lingkup kesiapan manajemen terhadap implementasi perubahan organisasi pengelolaan SDM single Grade di PT Pertamina (Persero) Marketing Operation Region V Surabaya.

\section{Perumusan Masalah}

Berdasarkan uraian latar belakang masalah yang telah diuraikan pada bagian sebelumnya maka rumusan masalah dalam penelitian ini adalah: Bagaimana Kesiapan Manajemen terhadap Implementasi Perubahan Organisasi Pengelolaan SDM Single Grade di PT Pertamina (Persero) Marketing Operation Region V Surabaya?

\section{Tujuan Penelitian}

Adapun tujuan utama dari penelitian ini adalah untuk menganalisis kesiapan manajemen perubahan organisasi pengelolaan SDM Single Grade di PT Pertamina (Persero) Marketing Operation Region $\vee$ Surabaya dengan menggunakan model Readiness for changes.

\section{Manfaat Penelitian}

Penelitian ini diharapkan untuk memberikan masukan kepada manajemen perusahaan PT Pertamina (Persero) Marketing Operation Region V Surabaya dalam mengetahui implementasi Perubahan Pengelolaan SDM Single Grade di PT Pertamina (Persero) Marketing Operation Region $\vee$ Surabaya, hambatan, dukungan serta konsekuensi pada saat penerapan, sehingga daapt diketahui prioritas perbaikan yang diperlukan guna kelancaran proses change dan tercapainya tujuan perubahan. 


\section{Roy Stefanus Fanggidae \\ Dwi ratmawati \\ Tri Siwi Agustina}

\section{LANDASAN TEORI DAN PENGEMBANGAN HIPOTESIS Perubahan Organisasi (Organizational Change)}

Menurut Cummings dan Worley (2008:4) "organizational change is more broadly focused and can apply to any kind of change, including technical and managerial innovations, organization decline, or evolution of system over time". Definisi tersebut berarti organization change meliputi berbagai macam change yang terjadi dalam suatu organisasi yang dikarenakan changing environments, competitor initiatives, technological innovation, globalization, dan restructuring.

Menurut Robbins, (1996) dalam Juniarti (2006: 16) bahwa perubahan adalah membuat sesuatu menjadi lain. Adapun perubahan terencana merupakan kegiatan perubahan yang disengaja dan berorientasi tujuan. Tujuan dari perubahan terencana: (1) perubahan itu mengupayakan perbaikan kemampuan organisasi untuk menyesuaikan diri terhadap perubahan dalam lingkungan (2) perubahan itu mengupayakan perubahan perilaku karyawan.

Menurut Sopiah (2008: 78) perkembangan organisasi adalah suatu proses perubahan variabel-variabel sistem yang spesifik yang diidentifikasi melalui melalui diagnosis organisasi dan tingkat perencanaan. Perubahan-perubahan mungkin saja berkaitan dengan tugastugas, tujuan strategis organisasi dan sistem pengendalian, sikap atau hubungan antar pribadi. Perubahan tambahan adalah suatu strategi yang evolusioner sehingga agen perubahan dapat menyesuaikan dengan keberadaan organisasi dan mengambil langkahlangkah menuju ke arah tujuan dilakukannya upaya-upaya perubahan.

Menurut Palmer, Dunford dan Akin (2009:86) terdapat 2 (dua) tipe perubahan organisasi yaitu (1) First-order, incremental change; dan (2) Second-order, discontinuous change. Incremental change meliputi penyesuaian dalam sistem, proses atau struktur, namun tidak meliputi fundamental change dalam strategi, nilai-nilai inti (core values) organisasi atau identitas organisasi. Incremental change berlangsung terus menerus \& bukan perubahan besar bagi keseluruhan organisasi. Sedangkan discontinuous change merupakan transformasi, radikal, dan secara fundamental mengubah inti dari organisasi. Second-order change ini bukan mengembangkan namun mentrasnformasi suatu organisasi.

Tabel II.1

Types of Changes

\begin{tabular}{|l|l|l|}
\hline \multicolumn{1}{|c|}{ Dimension } & \multicolumn{1}{c|}{ Incremental } & \multicolumn{1}{c|}{ Discontinuous } \\
\hline Anticipatory & $\begin{array}{l}\text { Tuning improving, } \\
\text { enhancing, developing: } \\
\text { first-order change }\end{array}$ & $\begin{array}{l}\text { Reorientation of identity or values- } \\
\text { frame bending }\end{array}$ \\
\hline Reactive & $\begin{array}{l}\text { Adaption } \\
\text { Internally initiated }\end{array}$ & $\begin{array}{l}\text { Re-creation } \\
\text { Fast change off all basic elements- } \\
\text { frame breaking, second-order } \\
\text { change }\end{array}$ \\
\hline
\end{tabular}

Sumber: Palmer, Dunford and Akin (Adapted from Nadler and Tushman, 1995). 2009. Managing Organizational Change. New York: McGraw-Hill.

Nadler and Tishman (1995) mengembangkan perbedaan antara incremental dan discontinuous change dengan membedakan dimensi yaitu apabila change menjadi reactive atau sebagai anticipatory change dalam lingkungan eksternal. Terdapat 4 kategori yaitu tuning, reorientation, adaption, dan re-creation (lihat tabel II.1).

Model pengelolaan perubahan organisasi pertama kali diungkapkan oleh Kurt Lewin, yang dikenal dengan konsep force-field yang diklasifikasikan sebagai model power-based karena menekankan kekuatan-kekuatan penekanan. Selama proses perubahan terjadi, 
akan terdapat kekuatan-kekuatan yang mendukung dan kekuatan-kekuatan yang menolak.

Melalui strategi yang dikemukakan Kurt Lewin, kekuatan pendukung akan semakin banyak dan kekuatan penolak akan semakin sedikit. Disimpulkan bahwa kekuatan tekanan (driving force) akan berhadapan dengan penolakan (resistance) untuk berubah. Perubahan dapat terjadi dengan memperkuat driving force dan melemahkan resistance to change.

Pendekatan yang dikemukan Kurt Lewin yang mencakup tiga langkah, yaitu unfreezing the status quo, lalu movement to the new state dan ketiga refreezing the new change to make it permanent. Hal ini dapat dilihat pada gambar II.1 berikut:

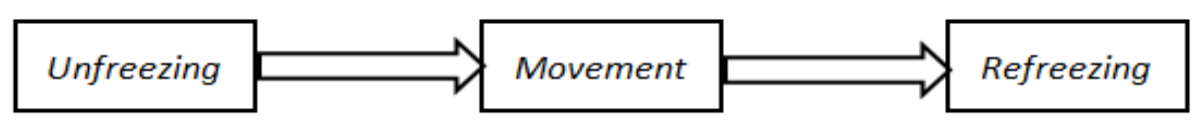

Sumber: Cummings, G. T \& C. G. Worley. 2008. Organizational Development and change. USA: South-Western Cengage Learning.

\section{Gambar II.1 Lewin's Planned Change Model}

Langkah-langkah pada gambar II.2 dapat diambil untuk mengelola perubahan yaitu seperti yang dijelaskan sebagai berikut:

1. Unfreezing, merupakan suatu proses penyadaran tentang perlunya, atau adanya kebutuhan untuk berubah. Focus pada tahap ini adalah menciptakan motivasi untuk berubah. Yang dilakukan pada proses ini adalah mulai mencairkan keadaan dan penyadaran kepada karyawan tentang kebutuhan untuk berubah dan bersiap-siap untuk menghadapinya. Unfreezing dapat dilakukan, misalnya melalui komando atau instruksi langsung pimpinan tertinggi, dimana semua pihak agar memberikan komitmen dan dukungan maksimal serta memonitor dengan ketat semua aktivitas yang terkait dengan perubahan atau implementasi program maupun sistem baru. Semua pihak yang terlibat harus bekerjasama dan menjadikan perubahan sebagai tantangan tersendiri bagi karyawan.

2. Movement, merupakan langkah tindakan, baik memperkuat driving force maupun memperlemah resistances. Langkah ini juga meliputi intervensi di dalam sistem untuk mengembangkan perilaku baru, nilai-nilai dan sikap melalui change di dalam struktur organisasi dan proses. Secara bertahap (step by step) tapi pasti, perubahan dilakukan. Jumlah penentang perubahan berkurang dan jumlah pendukung bertambah. Untuk mencapainya, hasil-hasil perubahan harus segera dirasakan.

3. Refreezing, pada proses ini yang dilakukan adalah tidak membuka peluang kepada karyawan untuk melaksanakan pekerjaan dengan cara-cara terdahulu. Segala permasalahan terkait perubahan harus langsung diatasi, sehingga karyawan tidak memiliki pilihan lain selain mengikuti perubahan yang ada. Perubahan yang telah berjalan di institusionalisasi sebagai standar dalam system kerja di perusahaan, kemudian dibuatkan kompetensi yang menjadi standar kebutuhan kompetensi dan pelatihan bagi berbagai jabatan yang ada di perusahaan. Jika berhasil maka jumlah penentang akan sangat berkurang, sedangkan jumlah pendukung makin bertambah.

Selama proses perubahan terjadi kekuatan-kekuatan yang mendukung dan yang menolak. Melalui strategi yang dikemukan oleh Kurt Lewin, kekuatan pendukung (driving forces) akan semakin banyak dan kekuatan penolak (restraining forces) akan semakin sedikit.

Secara keseluruhan model pendekatan klasik yang dikemukakan Lewin adalah seperti yang digambarkan pada gambar II.2. 


\section{Roy Stefanus Fanggidae \\ Dwi ratmawati \\ Tri Siwi Agustina}

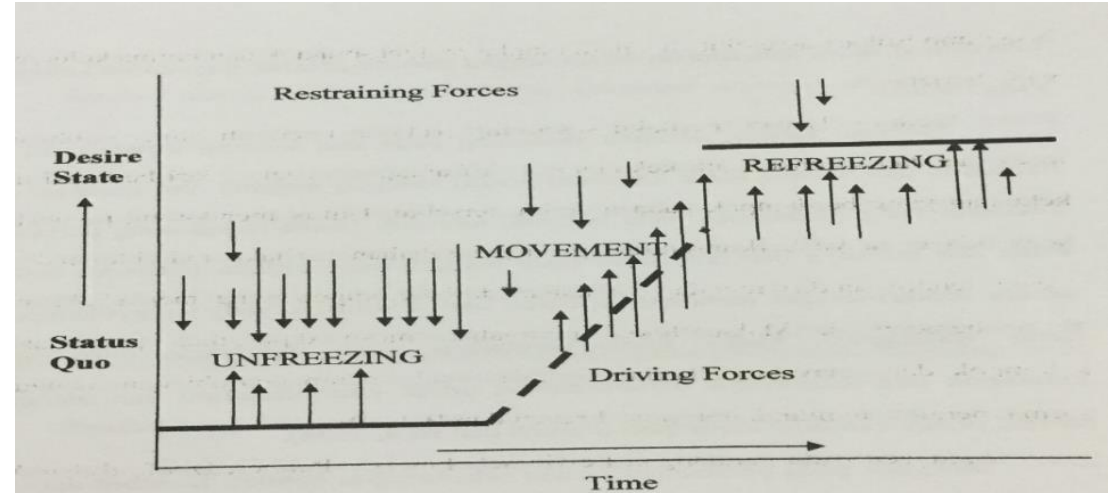

Sumber: Kurt Lewin, Field Theory in Social Science, 1951.

Gambar II.2

Lewin's Force Field Model

Menurut Lewin, perilaku seseorang pada saat tertentu dipengaruhi oleh intensitas dan valensi (baik kekuatan positif ataupun negatif) dari berbagai daya kekuatan yang berdampak pada individu tersebut. untuk mendorong perubahan, tidak ada gunanya berkonsentrasi pada pengubahan perilaku individu. individu secara sendiri-sendiri mendapat tekanan dari kelompok yang menyebabkannya harus beradaptasi. Maka, fokus perubahan mesti dipusatkan pada tataran kelompok dan selayaknya berkonsentrasi untuk mempengaruhi dan mengubah norma, peran, dan nilai kelompok (French dan Bell, 1984).

\section{Diagnosis for Change}

Setelah dibuat rencana perubahan (planning change) dilakukan fase selanjutnya yang disebut proses diagnosa. Diagnosa adalah proses untuk memahami sistem yang berfungsi pada saat ini meliputi pengumpulan informasi tentang operasional yang dijalankan saat ini, analisis data dan membuat saran untuk perubahan yang potensial maupun pengembangannya. Hal ini seperti yang dinyatakan oleh Cummings and Worley (2008:88):

"Diagnosis is the process of understanding a systems current functioning. It involves collecting pertinent information about current operations, analyzing those data, and drawing conclusions for potential change and improvement. "

Readiness for change merupakan variabel perantara antara strategi change management dengan hasil atau outcomes dari strategi tersebut. Hasil yang diinginkan (desired outcomes) biasanya merupakan kesuksesan dari implementasi. Prechange audit pada kesiapan organisasi dapat memunculkan indikasi hasil yang diinginkan dari change. Stewart (1994) dalam Palmer et al. (2009:144-146) menjabarkan bahwa terdapat 17 (tujuh belas) kunci elemen dari pendiagnosaan perubahan dengan menggunakan model Readiness for changes yaitu:

1. Sponsorship, yaitu adanya dukungan dari seseorang yang memiliki kekuatan (power) menolong suatu kelompok yang melakukan perubahan untuk menghadapi penolakan (resistance).

2. Leadership, yaitu sebuah kesuksesan akan dapat tercapai apabila terdapat kepemimpinan yang baik. Seseorang dapat dikatakan memiliki jiwa leadership yang baik apabila memiliki sifat "ownership" dimana terdapat tanggung jawb secara langsung terhadap apa yang akan diubah, dan memiliki pemikiran yang bersih terhadap suatu bisnis.

3. Motivation, yaitu timbulnya motivasi karyawan karena adanya perhatian dari top level manajemen dan apabila budaya organisasi telah menuju pengembangan yang berkelanjutan (continuous improvement). 
4. Direction, yaitu adanya top level manajemen yang bias diandalkan dalam mengerahkan seluruh karyawan untuk melakukan suatu tindakan dalam menghadapi tantangan perusahaan di masa depan.

5. Measurement, yaitu adanya pengukuran kinerja. Suatu organisasi memiliki ukuran kinerja untuk menentukan seberapa jauh proses perubahan menunjukkan hasil. Pengukuran kinerja akan berpengaruh pada sistem kompensasi dan reward.

6. Organizational context, yaitu apabila upaya perubahan yang dilakukan dapat menghubungkan permasalahan yang terjadi dalam organisasi dan dapat sesuai (fit) dengan tindakan strategi organisasi.

7. Processes or functions, yaitu adanya sifat fleksibel atau tidak kaku dalam mendesain ulang proses bisnis. Dalam hal ini dibutuhkan kesanggupan organisasi untuk mengubah beberapa proses yang bersifat critical dan mengorbankan kekuasaan (power) untuk kepentingan kelompok.

8. Competitor benchmarking, yaitu adanya program berkelanjutan yang bertujuan untuk membandingkan kinerja organisasi dengan pesaing agar dapat mengetahui kondisi maupun posisi organisasi di pasar.

9. Customer focus, yaitu apabila organisasi mengetahui siapa pelanggannya, apa kebutuhannya, dan melakukan kontak secara langsung dengan pelanggannya sehingga organisasi dapat melayani atau memperlakukan pelanggan dengan lebih baik.

10. Rewards, yaitu adanya penghargaan yang layak untuk para manajer dan seluruh karyawan ketika mereka mengambil resiko, berinovasi dan mencari solusi baru. Penghargaan pada kelompok lebih baik dibandingkan dengan penghargaan berdasarkan pencapaian individu.

11. Organizational structure, yaitu apabila suatu organisasi bersifat fleksibel. Perubahan akan sulit terjadi apabila suatu organisasi menerapkan struktur yang kaku yaitu struktur tidak berubah lebih dari 5 (lima) tahun dan apabila suatu organisasi mengalami reorganisasi berkali-kali dengan sedikit kesuksesan.

12. Communication, yaitu adanya komunikasi dua arah (two-way communication) yang diterapkan antara organisasi dan karyawan.

13. Organizational hierarchy, yaitu apabila terdapat level hirarki yang lebih pendek dan lebih sedikit karyawan pada tiap level. Hal tersebut untuk mencegah lambatnya proses pengambilan keputusan dan timbulnya sejumlah karyawan yang menggunakan kekuasaaan untuk menolak perubahan.

14. Prior experience with change, yaitu apabila organisasi telah berhasil dalam melaksanakan perubahan-perubahan penting di masa lampau.

15. Morale, adanya kenyamanan karyawan dalam bekerja pada suatu organisasi dan tingginya tanggungjawab individu. Tanda-tanda ketidaksiapan dalam berubah apabila semangat kelompok rendah, sedikit voluntary dengan upaya lebih, dan ketidakpercayaan.

16. Innovation, yaitu apabila organisasi selalu bereksperimen; ide-ide baru dilaksanakan dengan sedikit upaya; dan karyawan bekerja melewati batas internal tanpa banyak hambatan.

17. Decision making, yaitu apabila keputusandiambil dengan cepat. Ketidaksiapan ditandai dengan lambatnya pengambilan keputusan dan timbul banyak konflik selama proses pengambilan keputusan tersebut.

Menurut Prochaska (2006) dalam "The Four Levels of People's Readiness for Succesful Behavior Change" bahwa terdapat 4 (empat) level kesiapan manusia untuk kesuksesan perubahan perilaku yaitu: (1) Oblivious: tidak dapat melihat permasalahan, menolak perubahan dan upaya-upaya perubahan; (2) Contemplation: melihat kebutuhan untuk pengembangan dan memikirkan bagaimana melakukan perubahan tersebut, namun seseorang dapat berhenti pada level ini dalam jangka waktu lama untuk memikirkan perubahan; (3) Preparation: fokus pada solusi, rencana tindakan, sadar akan permasalahan dan mencari cara untuk memecahkan suatu permasalahan; (4) Action: rencana dilakukan dan tindakan dimulai untuk melakukan perubahan. Change membawa reaksi yang 


\section{Roy Stefanus Fanggidae \\ Dwi ratmawati \\ Tri Siwi Agustina}

berbeda-beda pada setiap karyawan, maka itu solusi dari managing change adalah dengan memfokuskan pada karyawan.

Perubahan akan mempengaruhi siapapun baik pihak manajemen ataukah karyawan. Change bias ditanggapi dengan reaksi positif ataukah reaksi negatif (resistance) bergantung pada jenis dan derajat perubahan itu sendiri untuk mencapai keberhasilan suatu program perubahan maka setiap orang harus siap dan mampu mengubah perilakunya. Hal ini sangat bergantung pada apa yang mempengaruhi perilaku dan apa pula yang mendorong seseorang untuk berubah (Mangkuprawira, 2009).

\section{Single Grade}

Single Grade merupakan salah satu bentuk perubahan terhadap system pembinaan serta remunerasi sebagai bentuk upaya Perusahaan untuk menuju menjadi perusahaan kelas Dunia. Kompensasi (compensation) menjadi sebuah area kritis dalam pengelolaan SDM dan salah satu aspek yang secara signifikan berdampak kepada perilaku pekerja. Agar efektif, compensation harus di persiapkan oleh pekerja sebagai adil, kompetitif di pasar, akurat, memotivasi dan mudah dipahami.

Ada beberapa langkah untuk merancang struktur penggajian, yaitu:

a. Job Analysis

Di Pertamina disebut uraian jabatan, yang mencakup nama jabatan, tugas pokok jabatan, tugas dan tanggung jawab serta gambaran konteks pekerjaan. Juga termasuk pengetahuan, ekahlian dan kemampuan yang dibutuhkan untuk dapat melaksanakan pekerjaan tersebut.

b. Job Evaluation

Proses menilai 'kelayakan' relatif dari pekerjaan atau jabatan-jabatan dalam sebuah organisasi. Hasil dari job evaluation adalah struktur atau ranking hirarki jabatan yang berlaku secara internal di organisasi itu. Secara umum, job-based evaluation lebih banyak dilakukan dibandingkan person-based evaluation. Job evaluation atau person evaluation dilakukan untuk memastikan ada kesesuaian penggajian secara internal dan dipersepsikan adil oleh pekerja.

c. Pay Policy Identification

Proses untuk menentukan apakah kompensasi yang ditawarkan organisasi ingin lebih tinggi dari pasar, lebih rendah dari pasar atau menyamai pasar. Kebijakan atau strategi penggajian akan mempengaruhi ketertarikan dan retensi pekerja di organisasi tersebut.

d. Pay Survey Analysis

Proses untuk menganalisis data kompensasi yang dikumpulkan dari perusahaan/organisasi lain dalam sebuah survey di pasar tenaga kerja yang relevan dengan organisasi tersebut. Mengumpulkan data penggajian di luar (seperti gaji/upah pokok, bonus, stock options dan benefit) adalah penting untuk menjaga kompensasi sebuah organisasi kompentitif dalam industrinya.

e. Pay Structure Creation

Sebagai pelengkap struktur penggajian, golongan gaji dan rentang gaji dalam sebuah regresi sederhana untuk membangun market pay line.

f. Job Based Pay vs Person Based Pay

Job based pay membayar pekerjanya berdasarkan jabatan atau posisi yang ditugaskan kepada mereka, dan tidak bergantung pada keahlian yang dimiliki. Sementara person based pay yang bias dipecah menjadi dua jenis yaitu skill based pay dan competences based pay, menghubungkan pay structures dengan tingkat kompetensi yang dimiliki oleh seorang pekerja dengan pekerjaannya. Person based structures membayar individu berdasarkan seluruh keahlian (atau kompetensi) yang dimilikinya dan tidak bergantung kepada apakah seluruh keahlian atau kompentensi itu digunakan dijabatannya atau hanya sebagian saja. 


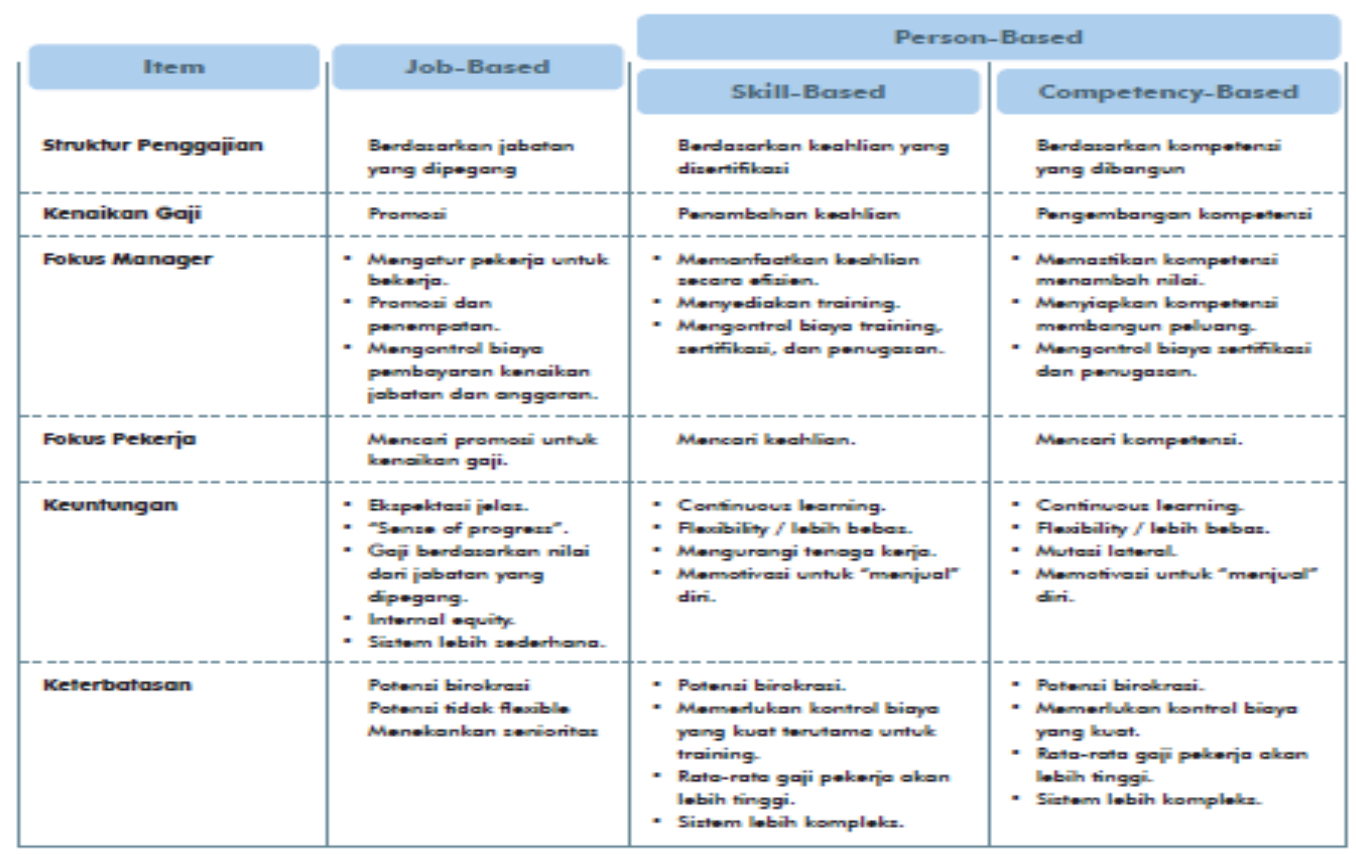

Sumber: Buletin Energia Pertamina No.08/THN XLVIII/Agustus 2013

Gambar II.3

Perbedaan Signifikan antara Job-Based Pay dan Person-Based Pay

Kedua jenis pay-structures di atas merupakan dua kubu ekstrim, dengan segala keuntungan dan keterbatasannya. Job-based pay lebih cocok digunakan untuk organisasi berskala besar yang membutuhkan keseimbangan atau kesetaraan, sementara personbased pay cocok digunakan ketika sebuah organisasi bisa mengidentifikasi secara jelas kualifikasi individu yang dibutuhkan.

\section{METODE PENELITIAN \\ Pendekatan Penelitian}

Pendekatan penelitian yang digunakan dalam kajian ini adalah jenis deskriptif kualitatif. Penelitian kualitatif adalah suatu metode yang digunakan untuk menemukan pengetahuan terhadap subjek penelitian pada suatu saat tertentu. Sedangkan penelitian deskriptif merupakan penelitian yang dimaksudkan untuk mengumpulkan informasi mengenai subjek penelitian dan perilaku subjek penelitian pada suatu periode tertentu. Penelitian kualitatif deskrptif berusaha mendeskripsikan seluruh gejala atau keadaan yang ada, yaitu keadaan gejala menurut apa adanya pada saat penelitian dilakukan.

Strauss dan Corbin (2003:4-5) bahwa pendefinisian metode penelitian kualitatif perlu mencakup cara data dianalisis karena menurut mereka, adakalanya penelitian dilakukan dengan wawancara mendalam yang merupakan teknik pengumpulan data penelitian kualitatif, tetapi kemudian peneliti mengkualifikasikan data kualitatif yang telah terkumpul dan seterusnya melakukan analisis statistik.

Jenis penelitian deskriptif kualitatif merupakan penelitian yang dilakukan dengan tujuan untuk memperoleh pemahaman terhadap adanya fenomena tentang apa saja yang dialami oleh subjek penelitian secara holistik dan dengan cara deskripsi yang ditunjukkan dalam bentuk kata-kata dan Bahasa dilakukan pada suatu konteks khusus yang bersifat alamiah dan dengan memanfaatkan berbagai metode alamiah (Moleong, 2012:7). Jenis penelitian deskriptif kualitatif yang digunakan pada penelitian ini dimaksudkan untuk 


\section{Roy Stefanus Fanggidae \\ Dwi ratmawati \\ Tri Siwi Agustina}

memperoleh informasi mengenai implementasi perubahan organisasi pengelolaan SDM single grade di PT Pertamina (Persero) Marketing Operation Region V Surabaya.

\section{Tujuan Study: Explanatory}

Metode penelitian yang digunakan dalam penelitian ini adalah studi kasus dengan menggunakan pendekatan kualitatif. Menurut Yin (1994) suatu penelitian studi kasus dapat dibedakan dalam tiga tipe yaitu studi kasus Explanatoris, Eksploratoris dan Deskriptif. Perbedaan pada ketiga tipe ini sangat jelas. Untuk studi kasus exploratoris, lebih menggali sesuatu yang belum ada atau mencoba menemukan sesuatu, pada studi kasus eksplanatoris menjelaskan fenomena yang terjadi dan pada studi kasus deskriptif lebih pada menggambarkan fenomena yang ada. Proses Implementasi Perubahan Organisasi pada Pengelolaan SDM dari Dual Grade ke Single Grade dalam penelitian ini sangat cocok untuk menggunakan tipe eksplanatory (eksplanatoris) dengan melakukan single case study, hanya satu kasus saja yang dibahas pada penelitian ini dan melihat sejauh mana implementasi Perubahan Organisasi pada Pengelolaan SDM dari Dual Grade ke Single Grade di PT Pertamina (Persero) Marketing Operation Region V Surabaya hingga saat ini, pemikiran ini yang mendasari dilakukannya penelitian dengan single case study.

\section{Holistic Single Case Study}

Penelitian ini hanya melihat sejauh mana proses perubahan yang terjadi pada pengelolaan SDM dari Dual Grade ke Single Grade di PT Pertamina (Persero) Marketing Operation Region $\vee$ Surabaya hingga saat ini dan yang secara umum dapat diartikan sebagai satu kesatuan yang dibentuk dari beberapa bagian dan pekerjaan, dimana setiap individu, pekerjaan, peraturan, strategi dan sebagainya diteliti sebagai suatu kesatuan dalam organisasi, sehingga digunakan Holistic Case Study.

\section{Desain Penelitian Holistic Single Case Study}

Desain penelitian ini menggunakan lima komponen penting dalam desain penelitian menurut Yin (1994, 20): (1) a study questions, (2) its propositions, if any (3) its unit(s) of analysis, (4) the logic linking the data to the propositions, and (5) the criteria for interpreting the findings.

\section{Prosedur Pengumpulan Data}

Prosedur pengumpulan data merupakan cara mengumpulkan data yang dilakukan agar hasil akhir penelitian mampu menyajikan informasi yang valid dan reliable. Tahapantahapan pengumpulan data dalam penelitian ini adalaha sebagai berikut:

1. Survey pendahuluan untuk mendapat gambaran tentang PT Pertamina (Persero) Marketing Operation Region $\mathrm{V}$ dan berbagai permasalahan yang terjadi di dalamnya.

2. Pengorganisasian penelitian yang terdiri dari tahap persiapan, pencarian jurnal dan teori-teori yang terkait.

3. Pengumpulan data yang dapat mengidentifikasi kinerja yang ada pada obyek penelitian.

4. Pengumpulan data yang dilakukan dengan cara: a. Wawancara terstruktur, b. Pengamatan langsung (observation, c. Dokumentasi

5. Evaluasi hasil pengumpulan data yang meliputi proses perubahan yang telah berlangsung hingga saat ini dan kinerja organisasi setelah dilakukannya perubahan tersebut. 
Teknik analisis yang dilakukan dalam penelitian ini:

1. Menganalisis setiap data yang relevan, yaitu proses change Pengelolaan SDM dual grade ke single grade yang berlangsung hingga saat ini sesuai dengan konsep pendiagnosaan organizational change menurut Stewart dalam Palmer et al (2009:144146) yang merujuk pada tujuh belas kunci elemen, serta reaksi dari pelaku organisasi terhadap change.

2. Menganalisis sejauh mana respon dari pelaku organisasi terhadap proses change menuju Pengelolaan SDM single grade yang berlangsung hingga saat ini dipengaruhi oleh sponsorship, leadership, motivation, direction, measurement, organizational context, processes or function, rewards, organizational structure, communication, organizational hierarchy, prior experience with change, morale, innovation, dan decision making. Dan akhirnya menganalisis implementasi penerapan single grade guna kesuksesan proses change.

3. Melakukan proses pattern-matcing. Untuk membandingkan cara pikir secara empiris dan logis yang didasarkan pada suatu pola tertentu yang didasarkan pada suatu atau beberapa prediksi tertentu dengan apa yang ditemukan selama melakukan penelitian.

4. Melakukan chain of evidence, dengan menganalisis keterkaitan diantara data yang dikumpulkan dalam penelitian case study ini.

5. Melakukan cek ulang (cross check) antara persepsi pimpinan dengan persepsi karyawan. Perbedaan perspektif dari setiap sudut pandang mengenai proses change dapat diketahui dari sudut pandang pimpinan dan karyawan sehingga akhirnya bias di dapatkan solusi terbaik.

\section{HASIL DAN PEMBAHASAN}

\section{Pembahasan sponsorship berkaitan dengan proposisi}

Pada elemen sponsorship, perlu adanya dukungan pimpinan untuk melakukan suatu perubahan dan menghadapi resistensi. Pimpinan menyadari bahwa perubahan pengelolaan SDM single grade perlu dilakukan dalam mendukung PT Pertamina (Persero) menuju menjadi perusahaan kelas dunia. Perubahan terhadap sistem pembinaan serta remunerasi single grade merupakan perubahan kearah yang lebih baik sehingga pimpinan memberikan dukungan dalam bentuk sosialisasi dan sering berdialog dengan seluruh pekerja sehingga dapat mengurangi efek-efek negatif perubahan.

Karyawan pada middle level management, yaitu Unit Manager HR Jatim Balinus menyatakan bahwa kebijakan pengelolaan single grade dikeluarkan Pertamina secara top down dari Kantor Pusat dan diberikan ke Unit untuk dilaksanakan sehingga pimpinan sangat mendukung ketentuan-ketentuan baik aturan, tahapan yang berlangsung, sehingga implementasi dapat berjalan dengan baik.

Karyawan pada tingkat staf, yaitu Senior Supervisor dan Junior officer menyatakan bahwa pimpinan sangat mendukung keputusan yang sudah dibuat SDM Korporat terkait single garde. Seiring implementasi single grade banyak permasalahan yang muncul karyawan merasakan pimpinan tidak terlalu fokus dalam menyelesaikan anomali.

Berdasarkan pembahasan di atas, dapat dilihat bahwa terdapat kesamaan pandangan antara pimpinan, middle level management, dan karyawan dalam dukungan perubahan pengelolaan SDM single grade. Pimpinan dalam mendukung perubahan ini harus membentuk tim dalam melakukan evaluasi mengenai GAP analisis antara golongan jabatan dengan golongan upah yang selama ini ada.

\section{Pembahasan leadership berkaitan dengan proposisi}

Proses change dapat berjalan sukses apabila terdapat kepemimpinan yang baik. Gaya leadership menurut Kurt Lewin merupakan cara dan pendekatan untuk memberikan arah, mengimplementasikan rencana, dan memotivasi orang. Pimpinan PT. Pertamina (Persero) Marketing Operation Region $\vee$ Surabaya memiliki gaya kepemimpinan yang partisipatif atau biasa disebut demokratis. Gaya ini melibatkan pemimpin termasuk satu atau lebih karyawan dalam proses pengambilan keputusan untuk menentukan apa yang harus 


\section{Roy Stefanus Fanggidae \\ Dwi ratmawati \\ Tri Siwi Agustina}

dilakukan dan bagaimana melakukannya. Namun, pemimpin mempertahankan otoritas pengambilan keputusan akhir.

Pimpinan PT. Pertamina (Persero) Marketing Operation Region V Surabaya merupakan sosok pimpinan yang mampu menangani konflik, pintar dalam menyikapi suatu permasalahan dan membuat suatu solusi, berani mengambil resiko, baik dan perhatian ke karyawan secara pribadi maupun untuk kepentingan perusahaan dan menekankan pada teamwork untuk mencapai tujuan perusahaan. Pimpinan juga mendorong karyawan agar mempunyai kompetensi sehingga dengan perubahan singe grade karyawan menjadi pekerja yang berkualitas.

\section{Pembahasan motivation berkaitan dengan proposisi}

Perhatian pimpinan pada karyawan dan pengembangan yang terjadi dalam perusahaan dapat menimbulkan motivasi pada karyawan. Pimpinan melihat bahwa dengan adanya single grade ada tempat-tempat/jabatan yang belum nyaman dan akhirnya perusahaan mengalah dengan memberikan kompensasi yang kurang lebih minimal sama dengan kompensasi yang sebelumnya. Karyawan pada middle level management, khususnya Finance Manager Marketing Operation Region $\vee$ mempunyai pandangan yang sama dengan pimpinan, bahwa kebijakan pengelolaan single grade perusahaan paling inti tidak boleh mengakibatkan turunnya perubahan penghasilan atau take home pay dari seluruh karyawan sebagai bentuk motivasi agar karyawan dapat meningkatkan kinerjanya.

\section{Pembahasan direction berkaitan dengan proposisi}

Pimpinan yang bisa diandalkan dalam memberikan arahan pada seluruh karyawan untuk bertindak dalam menghadapi tantangan perusahaan sangat diperlukan untuk proses change. Arahan yang disampaikan pimpinan dalam proses change perusahaan terkait pengelolaan single grade kepada karyawan agar supaya tetap dalam jalur kompetensi yang tetap bagus, serta perusahaan memberikan kesempatan seluas-luasnya kepada pekerja untuk mengambil pelatihan, mengikuti pembelajaran merupakan bentuk dukungan perusahaan terhadap seluruh karyawan untuk maju. Karyawan mengungkapkan bahwa terkait single grade masih sebatas di terima lebih dahulu dan dijalankan karyawan sesuai PRL konversi Dual grade ke single grade, setelah ada evaluasi akan dipindahkan/disesuaikan ke PRL sesuai kompetensi. Serta kebijakan tersebut dilakukan pimpinan tapi tidak pernah di sampaikan ke karyawan.

\section{Pembahasan measurements berkaitan dengan proposisi}

Pengukuran kinerja diperlukan untuk menentukan seberapa jauh proses perubahan yang dilakukan perusahaan menunjukkan hasil. Kinerja PT. Pertamina (Persero) Marketing Operation Region $\vee$ Surabaya dilihat dari produktivitas secara keseluruhan meliputi produktivitas dari sisi karyawan, pemasaran dan Keuangan. Pengukuran kinerja karyawan dilakukan dengan metode $360^{\circ}$ yang ada di people review artinya suatu pengukuran yang sangat fair merubah dari pola pengukuran yang dilakukan oleh atasan sehingga sebetulnya dengan pengukuran ini pekerja diberikan kesempatan seluas-luasnya untuk mengembangkan diri, mengembangkan diri menjadi lebih baik di mata atasan, teman maupun dimata teman-teman yang ada di sekitarnya.

\section{Pembahasan organizational context berkaitan dengan proposisi}

Upaya perubahan yang dilakukan harus mampu menghubungkan permasalahan yang terjadi dalam perusahaan dan dapat sesuai (fit) dengan strategi perusahaan. Secara umum, upaya perubahan yang berlangsung hingga saat ini perlu penyempurnaan dan perbaikan agar sesuai dengan pengelolaan SDM single grade. Upaya yang dilakukan seperti misalnya setiap karyawan diassessment atau diukur kompetensinya serta career path seluruh pekerja.

\section{Pembahasan processes berkaitan dengan proposisi}


Proses change mudah dilakukan apabila perusahaan bersifat fleksibel dalam penyesuaian kegiatan organisasi. Dalam menghadapi situasi anomali penyesuaian PRL karyawan, pimpinan melakukan coaching untuk mengurangi hambatan-hambatan dari perubahan organisasi yang harus dilakukan. Penyesuaian ini masih di kaji di Kantor Pusat untuk memperbaiki sistemnya serta adanya evaluasi berkelanjutan atas implementasi single grade.

\section{Pembahasan rewards berkaitan dengan proposisi}

Proses change akan mudah dilakukan apabila ada penghargaan yang layak untuk para manajer dan seluruh karyawan ketika mengambil resiko, berinovasi dan mencari solusi baru. PT Pertamina (Persero) Marketing Operation Region $V$ tidak memberikan rewards berupa bonus secara individu, namun bonus diberikan tiap tahun sekali pada seluruh karyawan apabila penjualan dan produksi mencapai target. Sistem reward sudah di atur berdasarkan peraturan yang dibuat bersama antara perusahaan dengan Serikat Pekerja dan di update setiap tahun di Perjanjian Kerja Bersama (PKB). Sistem reward di perusahaan sudah berjalan baik karena terakomodir di merit increase.

\section{Pembahasan organizational structure berkaitan dengan proposisi}

Struktur organisasi yang bersifat fleksibel akan memudahkan proses change dibandingkan struktur yang kaku. Struktur organisasi di PT Pertamina (Persero) Marketing Operation Region $\vee$ Surabaya bersifat fleksibel menyesuaikan perubahan yang terjadi dalam perusahaan. Organisasi dibentuk berdasarkan perusahaan akan dibawa ke arah mana. Perubahan organisasi single grade merupakan simplikasi pengurangan orang tapi pengembangan tanggungjawab seseorang dinaikan gradenya karena pekerjaannya bertambah. Dengan adanya pengelolaan single grade beberapa struktur organisasi fungsi disesuaikan dengan kondisi actual di lapangan, penyesuaian tersebut dilakukan oleh HR bersama fungsi terkait.

\section{Pembahasan communication berkaitan dengan proposisi}

Proses change akan lebih mudah dan lancar apabila terjalin komunikasi dua arah antara pimpinan dan karyawan. komunikasi yang dijalin antara pimpinan dengan karyawan di PT Pertamina (Persero) Marketing Operation Region $\vee$ telah dilakukan secara rutin. Pimpinan telah memberikan sosialisasi pada seluruh karyawan. Sosialisasi ini diadakan bukan saja Unit tetapi juga oleh Kantor Pusat dan mewadai pekerja. PT Pertamina (Persero) Marketing Operation Region $V$ sudah ada media untuk pertemuan antara pimpinan dan karyawan yang pertama melalui rapat management, otomatis semua informasi dari pimpinan akan di sampaikan ke Manajer dan Manajer akan menurunkan ke bawahannya, kemudian melalui Group Management MOR $\vee$ di BBM (Blackberry Messanger) untuk penyampaian informasi serta mengakrabkan dan mensolitkan management, sharing informasi. Pimpinan menyampaikan informasi juga melalui event-event misalnya halal bi halal maupun coffee morning.

\section{Pembahasan organizational hierarchy berkaitan dengan proposisi}

Proses change akan dapat berjalan dengan mudah apabila terdapat hirarki yang pendek dalam perusahaan. Dengan adanya pengelolaan single grade di PT Pertamina (Persero) Marketing Operation Region V, grade jabatan yang lebih tinggi lebih sedikit dari grade jabatan yang lebih rendah.

\section{Pembahasan prior experience with change berkaitan dengan proposisi}

Perusahaan yang telah berhasil melakukan perubahan penting di masa lampau dapat membuat proses change lebih mudah karena dapat belajar dari pengalaman. Perubahan penting yang pernah dilakukan PT Pertamina (Persero) di masa lampau yaitu perampingan pekerja secara besar-besaran sehingga mengurangi beban perusahaan. Jumlah pekerja dimasa lampau yaitu sebanyak 50.000 orang pekerja saat ini jumlah pekerja tersisa 13.000 an orang pekerja dengan pekerjaan yang tetap (sama seperti masa lampau). 


\section{Roy Stefanus Fanggidae \\ Dwi ratmawati \\ Tri Siwi Agustina \\ Pembahasan morale berkaitan dengan proposisi}

Proses change dapat berjalan lancar apabila karyawan merasakan kenyamanan dalam bekerja dan tingginya tanggungjawab individu. PT Pertamina (Persero) Marketing Operation Region $\vee$ memiliki kenyamanan dan tanggungjawab tergantung pada individu masing-masing. Karyawan perlu diakui, di rangkul, di dorong, diawasi, atau lebih tepatnya lagi adanya perhatian dari atasan sehingga karyawan lebih produktif dalam bekerja.

\section{Pembahasan innovation berkaitan dengan proposisi}

Proses change dapat mudah dan lancar dijalankan apabila perusahaan selalu berinovasi dengan mengeluarkan ide-ide baru. Pimpinan menyatakan bahwa inovasi tidak dibatasi ruang geraknya kepada seluruh karyawan. Perusahaan sudah mensupport karyawan melalui tempat, waktu, ruang untuk karyawan berinovasi baik itu melalui kegiatan Mutu, kegiatan Kualitas Manajemen, sharing manajemen. Setiap karyawan harus melakukan inovasi-inovasi berupa improvement bagi kepentingan perusahaan, siapa-siapa yang dapat memberikan nilai lebih tentu saja akan bernilai lebih yang berpengaruh terhadap kompetensi atau penilaian kemampuan masing-masing karyawan.

\section{Pembahasan decision making berkaitan dengan proposisi}

Perusahaan dikatakan siap melakukan perubahan apabila keputusan diambil dengan cepat, pengambilan keputusan yang lambat menandakan banyak konflik selama proses pengambilan keputusan. Pengambilan keputusan oleh Pimpinan PT Pertamina (Persero) Marketing Operation Region V Surabaya terkait single grade secara kolektif tidak memutuskan sendiri akan tetapi menanyakan kepada HR sebagai pengelola utama serta Manager yang memahami tentang anak buahnya, dalam mengumpulkan informasi dan keputusan yang akan diambil.

Karyawan pada middle level management menyatakan keputusan yang di ambil pimpinan di MOR $V$ secara top down, serta lebih open minded dimana saat pimpinan mengambil keputusan selalu mencari masukkan juga dari Manajemen fungsi terkait.

Penerapan proses change di PT Pertamina (Persero) yang ditunjukkan dalam tujuh belas kunci elemen pendiagnosaan perubahan berimplikasi pada meningkatnya kinerja karyawan. Upaya-upaya perubahan yang dilakukan perusahaan menuntut karyawan untuk meningkatkan kompetensi dan kemampuan diri serta bertanggungjawab penuh terhadap tugas-tugas yang diberikan.

Penilaian prestasi kerja merupakan salah satu pendukung dalam kinerja karyawan. dalam rangka pembinaan dan pengembangan karyawan, setiap 6 bulan dilaksanakan evaluasi prestasi kerja people review yang telah ditetapkan perusahaan. Penilaian prestasi kerja di PT Pertamina (Persero) hanyalah sebagai alat Ukur dan bersifat normatif. Dengan adanya single grade memacu karyawan untuk berprestasi dan meningkatkan kemampuan sehingga pimpinan dapat memutuskan apakah karyawan tersebut layak mendapatkan promosi atau kenaikan jabatan.

Pimpinan dan karyawan menyadari pentingnya penyempurnaan terhadap penilaian kinerja karyawan agar sistem berjalan lebih baik. Faktot-faktor dalam penilaian prestasi kerja karyawan perlu diperbaharui menjadi lebih objektif. Pimpinan juga menyadari bahwa terdapat kelemahan di PT Pertamina (Persero) yaitu penyempurnaan career path untuk karyawan dibawah middle level management.

\section{SIMPULAN DAN SARAN Simpulan}

Berdasarkan hasil analisis dan pembahasan penelitian mengenai kesiapan manajemen implementasi perubahan organisasi pengelolaan SDM single grade di PT Pertamina (Persero) Marketing Operation Region $V$ Surabaya, maka dapat diambil kesimpulan Implementasi Perubahan Organisasi Pada Pengelolaan SDM dari Dual Grade ke Single Grade di PT Pertamina (Persero) Marketing Operation Region V Surabaya telah berlangsung dengan baik. Proses change dapat dilakukan dengan mudah dan lancar karena adanya faktor pendukung (driving force) dari 17 elemen (tujuh belas) elemen kunci 
change, yaitu adanya dukungan atau sponsorship yang diberikan pimpinan, adanya leadership pimpinan yang baik, adanya motivation dari pimpinan ke pekerja, adanya arahan atau direction yang jelas dari pimpinan, adanya measurement atau pengukuran kinerja, adanya organizational context atau upaya perbaikan yang dilakukan perusahaan sesuai dengan orientasi strategi pengelolaan SDM single grade, adanya processes penyesuaian kegiatan organisasi, adanya reward berupa bonus yang diberikan tiap tahun sekali kepada seluruh karyawan apabila penjualan dan produksi mencapai target, organizational structure yang fleksibel, adanya komunikasi dua arah antara pimpinan dan karyawan yang terjalin dengan baik, keberhasilan perusahaan melakukan perubahan yang penting di masa lampau, adanya morale yang ditunjukkan dengan tanggungjawab yang besar dari karyawan, adanya innovation yang dilakukan secara terus menerus, dan adanya pengambilan keputusan yang tepat oleh pimpinan. Hasil triangulasi dengan melakukan cek ulang (cross check) antara persepsi pimpinan, karyawan dan pelanggan tentang perubahan pengelolaan SDM single grade menunjukkan beberapa temuan faktor penghambat proses change. Faktor penghambat proses change tersebut adalah sponsorship dari pimpinan ke karyawan ketika adanya anomali atas implementasi single grade pimpinan kurang fokus dalam penyelesaiannya, motivation yang diberikan pimpinan dalam proses kenaikan golongan masih mengadopsi pola lama yaitu pola senioritas, masih adanya penyempurnaan career path karyawan dibawah middle level management, kurangnya pengembangan terhadap temuan/OFI, adanya double job pekerjaan yang dilakukan karyawan saat ini. Faktor-faktor penghambat dapat menghambat proses change ke depan, karena perubahan lingkungan eksternal sangat dinamis sehingga perusahaan perlu melakukan penyempurnaan pada hal-hal yang belum maksimal agar tetap dapat bersaing. Pada penelitian case study didapatkan hasil yang kemudian disimpulkan bahwa dinamika proses change pada PT Pertamina (Persero) Marketing Operation Region V sudah pada tahapan moving sesuai dengan konsep Lewin's planned change model dimana perusahaan telah mengambil langkah tindakan, baik memperkuat driving force maupun memperlemah resistances. Langkah ini juga meliputi intervensi di dalam system untuk mengembangkan perilaku baru, nilai-nilai, dan sikap melalui change di dalam proses pengelolaan single grade. Perusahaan melakukan perubahan secara bertahap (step by step) tapi pasti. Hasil-hasil dari perubahan juga telah dirasakan walaupun belum sempurna namun perusahaan berniat menyempurnakannya.

\section{Saran}

Berdasarkan penelitian mengenai perubahan organisasi pada pengelolaan SDM dari dual grade ke single grade di PT Pertamina (Persero) Marketing Operation Region $V$ Surabaya, terdapat beberapa saran berkaitan dengan hasil yang didapatkan dari analisis dan pembahasan pada bab $\vee$ mengenai faktor penghambat (restraining forces) dalam pelaksanaan proses change. Saran ini diberikan sebagai masukan kepada PT Pertamina (Persero) Marketing Operation Region V Surabaya agar proses pengelolaan SDM single grade dapat dilaksanakan dengan mudah dan lancar.

Saran-saran tersebut adalah sebagai berikut:

1. Perlunya dukungan lebih dari pimpinan kepada karyawan dalam proses anomali jabatan yang terjadi dengan melibatkan HR maupun fungsi terkait dan tahapan proses penyesuaian jabatan disampaikan ke seluruh karyawan.

2. Perlu adanya monitoring terhadap proses change yang sedang berlangsung di perusahaan, untuk mengetahui dan evaluasi perkembangan proses internalisasi pemahaman tujuan, proses dan nilai-nilai perusahaan kepada karyawan.

3. Perlu adanya peningkatan motivasi karyawan, salah satunya melalui proses pemberian jabatan yang sesuai dengan kompetensi yang dimiliki pekerja tanpa melihat masa kerja dari karyawan.

4. Perlu adanya proses percepatan penyempurnaan career path karyawan dibawah middle level management dalam menunjang penentuan tujuan atau sasaran yang hendak dicapai dan menetapkan jalan dan sumber yang diperlukan karyawan untuk mencapai tujuan seefisien dan seefektif mungkin. 


\section{Roy Stefanus Fanggidae \\ Dwi ratmawati \\ Tri Siwi Agustina}

Penelitian dengan topik perubahan organisasi pada pengelolaan SDM single grade ini membuka peluang bagi peneliti berikutnya yang berminat pada manajemen sumber daya manusia, terutama bidang perubahan organisasi pengelolaan single grade di PT Pertamina (Persero) marketing Operation Region V Surabaya. Hal lain yang dapat dilakukan adalah melakukan penelitian ini dengan menggunakan metoode kuantitatif, sehingga dapat melihat pengaruh proses change pada kepuasan karyawan dan kepuasan pelanggan, atau meneliti kembali penelitian ini, namun dengan lebih banyak sumber bukti.

\section{DAFTAR REFERENSI}

Afrizal. 2014. Metode Penelitian Kualitatif. Jakarta: Penerbit PT. RajaGrafindo Persada

Cummings, G. T \& C. G. Worley. 2008. Organizational Development and change. USA: SouthWestern Cengage Learning.

Dessler, Gary. 2010. Manajemen Sumber Daya Manusia. Edisi kesepuluh. Jakarta: PT. Indeks

Fimelia. 2013. Lompatan Besar Menuju World Class. Energizing Asia: Energia. 11: 34-37.

Ginting, Erni D. 2013. Pay Structures: Job-Based atau Person-Based? . Energizing Asia: Energia. 8: 44-47.

Juniarti Indira, Ashari Bunyaanudin. 2006. Pengaruh Komitmen Organisasi dan Keterlibatan Kerja Islam Dengan Sikap terhadap Perubahan Organisasi.

Mangkuprawiraja, Sjafri. 2008. Manajemen Perubahan VS Krisis Manajemen Global. http://ronawajah.wordpress.com/2008/10/13/manajemen-perubahan-vs-krisismoneter-global/ diakses tanggal 09 juni 2015

Mathis Robert L, Jackson John H. 2006. Human Resources Management.Edisi Sepuluh. Jakarta: Penerbit Salemba Empat.

Masyhuri, Zainuddin M. 2008. Metodologi Penelitian-Pendekatan Praktis dan Aplikatif. Bandung: PT. Refika Aditama

Muhadi. 2013. Single Grade. Energizing Asia: Energia. 26: 3.

Mukhtar. 2013. Metode Praktis Penelitian Deskriptif Kualitatif. Jakarta: Referensi

Mustofa Hasan. 2001. Manajemen Perubahan: Modul Pembelajaran.

Noe, R. A.Hollenbeck, J. R, Wright, P. M. 2010. Manajemen Sumber Daya Manusia. (6th ed). Jakarta: Salemba Empat.

Palmer, I., R. Dunford, and G. Akin. 2009. Managing Organizational Change. New York: McGraw-Hill.

Prochaska, James. 2006. The Four Levels of People's Readiness for Succesful Behavior Change.

http://stephenslighthouse.sirsidynix.com/archives/2006/09/readiness_for_c.html diakses tanggal 09 Juni 2015

Putra Nusa. 2012. Metode Penelitian Kualitatif Pendidikan. Jakarta: Penerbit PT. Rajagrafindo Persada.

Sopiah. 2008. Perilaku Organisasional. Yogyakarta: Penerbit Andi.

Strauss, Anselm and Corbin Juliet. 2003. Dasar-Dasar Penelitian Kualitaitf: Tatalangkah dan Teknik Teoritisasi Data. Yogyakarta: Pustaka Pelajar.

Sugiyono. 2010. Metode Penelitian Kuantitatif Kualitatif dan R\&D. Bandung: Penerbit Alfabeta Winardi. 2006. Manajemen Perilaku Organisasi. Jakarta: Kencana.

Yin, Robert K. 2003. Studi Kasus (desain dan metode). Edisi revisi, terjemahan. Jakarta: PT RajaGrafindo Persada. 